JAMP: Jurnal Adminitrasi dan Manajemen Pendidikan

Volume 3 Nomor 4 Desember 2020, Hal : 342 - 351

Tersedia Online di http://journal2.um.ac.id/index.php/jamp/

ISSN 2615-8574 (online)

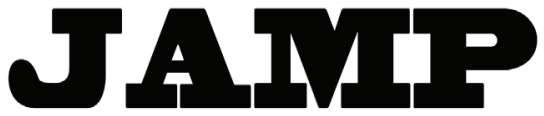

JURNAL ADMINISTRASI DAN MANAJEMEN PENDIDIKAN

\title{
IMPLEMENTASI MANAJEMEN PEMBELAJARAN DARING DENGAN PLATFORM WA, CR, M-Z DAN KEPUASAN MAHASISWA
}

\author{
Ika Korika Swasti \\ UPN Veteran Jawa Timur, Jl. Raya Rungkut Madya-Gunung Anyar-Surabaya \\ E-mail: ikaks.ma@upnjatim.ac.id
}

\begin{abstract}
The change of face-to-face learning strategy online requires the readiness of all academic cavities so that the educational objectives are achieved effectively and efficiently. The study aims to describe the implementation of online learning by using the platforms of Whatsapps (WA), Classroom (CR) and Google Meet/Zoom (MZ) in a student perspective. The research was conducted with a quantitatively descriptive comparison approach, with samples amounting to 117 people (census samples). The study was conducted on a semester II student UPN Management Veteran of East Java who followed the introductory management course. The results of this study were described and concluded that the thee platforms could meet the needs of students in obtaining information and interacting with the lecturer on online learning. Each platform has advantages and disadvantages. WA Platform Economical, Classroom and $\mathrm{M}-\mathrm{Z}$ need enough quota also in some geographical areas to be not smooth because of the network. Whatsapps, $\mathrm{CR}$ and $\mathrm{M}-\mathrm{Z}$ in online learning in an outline can meet the needs of students in interacting with both verbal, visual and non-verbal. But it is less able to meet students ' needs from the human side. In-face learning is still needed and considered more effective and meets the needs of students in interacting with lecturers or other students.
\end{abstract}

Keywords: online learning, face to face learning, student satisfactions

\begin{abstract}
Abstrak: Perubahan strategi pembelajaran dari tatap muka menjadi daring membutuhkan kesiapan semua civitas akademika agar tujuan pendidikan yang telah ditetapkan tercapai secara efektif dan efisien. Penelitian ini bertujuan untuk mendeskripsikan implementasi pembelajaran daring dengan pemanfaatan platform Whatsapps (WA), Classroom (CR) dan Google Meet/Zoom (MZ) dalam perspektif mahasiswa. Penelitian dilakukan dengan pendekatan kuantitatif deskriptif dan komparasi, dengan sampel sebesar 117 orang (sampel sensus). Penelitian dilakukan pada mahasiswa semester II Manajemen UPN Veteran Jawa Timur yang mengikuti mata kuliah Pengantar Manajemen. Hasil penelitian ini dideskripsikan dan disimpulkan bahwa ketiga platform tersebut dapat memenuhi kebutuhan mahasiswa dalam memperoleh informasi dan berinteraksi dengan dosen pada pembelajaran daring. Masing-masing platform memiliki kelebihan dan kekurangan. Platform WA irit menghemat pulsa, Classroom dan M-Z membutuhkan kuota yang cukup besar juga di beberapa area geografis menjadi tidak lancar karena jaringan. Whatsapps, $\mathrm{CR}$ dan M-Z dalam pembelajaran daring secara garis besar dapat memenuhi kebutuhan mahasiswa dalam berinteraksi baik verbal, visual, maupun non verbal. Tetapi kurang bisa memenuhi kebutuhan mahasiswa dari sisi manusiawinya. Pembelajaran tatap muka masih diperlukan dan dianggap lebih efektif dan memenuhi kebutuhan mahasiswa dalam berinteraksi dengan dosen ataupun mahasiswa lainnya.
\end{abstract}

Kata Kunci: Pembelajaran daring, pembelajaran tatap muka, kepuasan mahasiswa

Kegiatan belajar mengajar mengalami perubahan sejak dikeluarkannya Surat Edaran dari Mendikbud Nomor 36962/MPK.A/HK/2020 tertanggal 17 Maret 2020. Pembelajaran dilaksanakan secara daring sebagai upaya pencegahan terhadap perkembangan dan penyebaran pandemi Covid-19. Perubahan strategi pembelajaran yang tidak direncanakan sebelumnya, membutuhkan kesiapan baik dari 
institusi, pelaksana maupun dosen, dan mahasiswa. Kesiapan semua komponen civitas akademika dalam menghadapi perubahan pembelajaran dari tatap muka (regular) menjadi distancing learning membutuhkan proses adaptasi dan segera menyesuaikan diri serta mengaplikasikannya dalam proses pembelajaran demi tercapainya tujuan yang telah ditetapkan sebelumnya. Perubahan rencana taktis dengan memanfaatkan platform tertentu juga membutuhkan kesiapan dan kemauan untuk segera beradaptasi dan belajar. Pada tahap awal atau minggu pertama dilaksanakan (Maret 2020) dilaksanakan pembelajaran on-line adalah jadwal pelaksanaan Ujian Tengah Semester (UTS). Duffy (2010) menjelaskan bahwa lingkungan eksternal yang penuh dengan ketidakpastian dan bersifat kompleks mempengaruhi perguruan tinggi untuk menyesuaikan diri. Perubahan dalam organisasi menjadi suatu kebutuhan, karena adanya keterkaitan antara organisasi dan lingkungannya (Stephens \& Graham, 2010). Lingkungan akan terus berkembang dan berubah. Organisasi perlu mengikuti atau beradaptasi dengan perubahan tersebut. Organisasi tidak mungkin mengisolasi diri dari lingkungannya. Organisasi perlu mengikuti, memahami dan mengantisipasi perubahan dari lingkungan yang terjadi baik dari lingkungan internal maupun lingkungan eksternalnya.

Universitas Pembangunan Nasional "Veteran" Jawa Timur (UPNVJT) berdasarkan Surat Edaran Rektor Nomer: SE/05/UN63/TU/2020 dalam masa pandemi "Corona" menetapkan proses kegiatan belajar mengajar dengan metode Daring. Langkah ini sesuai dengan Surat Edaran Mendikbud Nomer: 3 Tahun 2020 tanggal 13 Maret 2020. Maka sejak 19 Maret 2020 terjadilah perubahan strategi pembelajaran yang awalnya tatap muka (regular) menjadi mahasiswa tetap belajar (kuliah) tetapi di rumah masing-masing secara online dengan dosennya sesuai jadwal yang sudah ditetapkan sebelumnya. Hussey (2000) dan Swasti (2018) menjelaskan bahwa perubahan merupakan salah satu aspek paling kritis untuk manajemen yang efektif. Perubahan membawa dampak dalam aspek yuridis, sosial dan aspek teknis. Aspek teknis terkaitkan dengan upaya dosen dan mahasiswa untuk segera mengenal, mempelajari dan mengimplementasikan media pembelajaran online seperti classroom, google meet, elearning dan alternatif lainnya yang selama ini sudah dimanfaatkan tapi belum maksimal atau belum pernah dilakukan. Pembekalan dan sosialisasi dilakukan oleh universitas kepada dosen pada tanggal 16 Maret 2020. Gerak cepat dilakukan untuk mewujudkan sistem yang baru dari pembelajaran regular menjadi pembelajaran daring.

Kuntarto (2017) serta Khusniyah \& Hakim(2019) menjelaskan bahwa terdapatperbedaan kemampuan dan peningkatan penyerapan terhadap materi kuliah dengan pembelajaran daring. Pembelajaran daring merupakan pilihan yang bisa dimanfaatkan dalam situasi pandemic saat ini (Syarifudin, 2020). Internet menjadi media untuk menyalurkan ilmu pengetahuan. Bentuk pembelajaran yang tidak harus tatap muka, dapat dilakukan kapanpun dan dimanapun tanpa terikat waktu. Keunggulan ini perlu dikelola oleh dosen dalam menyiapkan pembelajarannya dengan memanfatkan aplikasi dan fituryang memudahkan dosen dan mahasiswa seperti WA, CR atau M-Z. Social distancing merupakan anjuran pemerintah yang menuntut semua sektor kehidupan harus beradaptasi pada perubahan. Kesiapan setiap individu dalam beradaptasi terhadap perubahan akan mempengaruhi tercapainya tujuan dengan ditetapkannya perubahan tersebut. Febrianty (2020) menjelaskan bahwa tahap awal dalam tercapainya suatu perubahan adalah dengan mempersiapkan sumber daya manusia yang terlibat dalam perubahan. Setiap orang bertanggungjawab untuk keberhasilan perubahan agar adaptasi menjadi efektif dan melakukan antisipasi secara proaktif terhadap kondisi yang berubah. Kesiapan perubahan sebagai keyakinan dan sikap individu untuk menerima perubahan sebagai bagian dari cara dia mencapai tujuannya. Penerimaan atas perubahan sebagai sesuatu yang dibutuhkan dan cara untuk berhasil menyelesaikan perubahan. Ketika seseorang memiliki kesiapan untuk berubah maka diperlukan peran proaktif. Grant \& Ashford (2008) menjelaskan bahwa setiap sumber daya manusia yang ada dalam organisasi harus mempunyai konteks kerja yang dinamis. Tidak hanya menyesuaikan perilaku mereka untuk mengakomodasi perubahan, tetapi juga bertindak dan memulai perubahan itu sendiri secara proaktif. Perilaku proaktif adalah suatu tindakan yang diarahkan untuk memulai perubahan dengan kemauan sendiri.

Mahasiswa menempuh pendidikan dengan harapan dan tujuan meraih kesuksesan serta meraih peluang dan potensi untuk dapat memasuki dunia kerja. Proses menimba ilmu yang dijalani mahasiswa bersifat dinamis, sebagai seorang akademisi di perguruan tinggi akan selalu dihadapkan dengan tugas 
yang bersifat akademik maupun non akademik. Tugas yang bersifat akademik akan diberikan oleh masing - masing dosen pada setiap mata kuliah, bahkan dalam satu semester volume tugas tersebut mencapai sepuluh hingga lima belas makalah yang harus diselesaikan dengan baik dan tepat waktu (Papilaya \& Huliselan, 2016). Kinerja mahasiswa salah satu indikatornya terdeteksi dari terlesaikannya dengan baik tugas-tugas yang diberikan oleh dosennya. Volume tugas dengan jumlah yang banyak dan harus tepat waktu dan benar, membutuhkan kemampuan mahasiswa untuk mengelola waktu, tenaga dan pikirannya. Dosen perlu memberi perhatian pada kepentingan mahasiswa yang memiliki berbagai macam kebutuhan. Hasibuan (2008), menjelaskan bahwa terpenuhinya kebutuhan akan mempengaruhi motivasi kerja yang ada pada setiap individu untuk melakukan segala sesuatu yang lebih baik dari lainnya didalam melakukan kegiatan untuk mencapai tujuannya. Pada masa pandemi Covid 19 dengan diterapkan peraturan untuk melakukan pembelajaran dari rumah, maka dibutuhkan kesiapan untuk berubah baik dari mahasiswa, dosen maupun pendukung yang lainnya. Manajemen perubahan diperlukan untuk mencapai tujuan secara efektif dan efisien.

Menurut Desplaces (2005), kesiapan individu untuk menghadapi perubahan akan menjadi daya pendorong yang membuat perubahan itu akan memberikan hasil yang positif. Kesiapan individu untuk berubah mencerminkan pikiran, perasaan dan niat dari individu, yang mungkin atau tidak mungkin menyebabkan perilaku tertentu yang terkait dengan sikapnya. Volume tugas dengan jumlah yang banyak dan tingkat kesulitan dari tiap beban tugas tersebut, menuntut mahasiswa untuk menggunakan waktu dengan efisien dan efektif. Salamah, dkk (2020) juga menjelaskan bahwa orang tua dan sarana prasarana adalah faktor pendukung tercapainya tujuan school empowering program. Kinerja merupakan suatu hasil fungsi yang digunakan untuk menilai kegiatan seseorang atau sekelompok individu dalam suatu organisasi yang terdiri dari faktor internal maupun faktor eksternal yang berpengaruh terhadap prestasi kerja seseorang. Perubahan strategi pembelajaran dari reguler menjadi Daring tentunya perlu didukung oleh lingkungan si pembelajar (internal, eksternal) dan sarana dan prasarana yang memadai. Kemampuan finansial orang tua si pembelajar, dan lokasi atau daerah asal mahasiswa mempengaruhi efektifitas penggunaan media pembelajaran daring.

Kesiapan untuk berubah menurut Armenakis et al. (1993) dan Holt (2007) diawali dengan mempersiapkan diri untuk menerima perubahan karena pada hakikatnya manusia menjadi subjek dan objek perubahan serta mempunyai sifat resisten terhadap perubahan. Keyakinan dan sikap mahasiswa dalam menyikapi perubahan dalam strategi pembelajaran online dan kemampuan mahasiswa untuk berhasil menyelesaikan perubahan mempengaruhi kesiapan mahasiswa. Faktor terpenting dalam keberhasilan perubahan adalah sumber daya manusianya. Pemanfaatan platform $C R$ dalam pembelajaran dijelaskan oleh Chandra \& Nugroho (2017); Ischak, dkk (2019) bahwa flipped classroom memberikan persepsi positif dan memberikan kenyamanan dan memotivasi mahasiswa dalam proses pembelajaran. Selain classroom, media Whatsapp grup menurut Pratama \& Yusro (2016); dan Sukrillah, dkk (2018) dapat dimanfaatkan dalam menyampaikan informasi untuk sarana diskusi dan mendidik serta, memberikan pengaruh. Strategi pembelajaran daring dengan memanfaatkan platform yang ada diharapkan dapat meningkatkan hasil pembelajaran. Karenanya dibutuhkan kesiapan untuk perubahan di tingkat individu dipengaruhi oleh keyakinan bahwa: (a) mereka mampu menerapkan perubahan yang diusulkan, (b) usulan perubahan sesuai untuk dosen dan mahasiswa, (c) para pemimpin berkomitmen untuk perubahan yang diusulkan/dukungan manajemen, dan (d) perubahan membawa kebermanfaat bagi civitas akademika. Penjelasan tersebut menggambarkan bahwa keyakinan individu akan manfaat perubahan dan komitmen dari mahasiswa, dosen dan pendukung lainnya, berdampak pada kesiapan individu dalam menghadapi perubahan. Kesiapan merupakan salah satu faktor terpenting untuk mendukung inisiatif perubahan dengan melibatkan semua komponen yang ada dalam sistem pendidikan. Lehman, dkk (2005) antara lain menjelaskan bahwa kesiapan untuk berubah dapat dideteksi dari beberapa variabel seperti variabel motivasional, ketersedian sumber daya, nilai-nilai dan sikap positif yang dikembangkan, serta iklim organisasi yang mendukung perubahan. Kesediaan individu untuk berpartisipasi dalam kegiatan yang dilaksanakan dalam proses pembelajaran selama perubahan berlangsung diartikan sebagai kesiapan individu untuk berubah. 
Learning Technology Standards adalah salah satu standart yang terkait dengan sistem Pembelajaran daring yang memiliki tiga klasifikasi yaitu: (1) Quality Standart, (2) learning technology Standards, dan Related Standards (Ehler \& Pawlowski, 2006); (Bilfaqih \& Qomarudin, 2015). Standart kualitas, mendukung pengembangan kualitas untuk kebutuhan yang spesifik. Sedangkan untuk klasifikasi standart teknologi dalam pembelajaran berkaitan dengan Learning Management Systems (LMS) dan materi pembelajaran daring. Related Standards terkait dengan kualifikasi standart teknologi, proses atau legalitas. Standart kualitas dari pembelajaran daring akan mempengaruhi kepuasan mahasiswa. Prasetyaningrum (2009) menjelaskan bahwa kepuasan mahasiswa mempengaruhi loyalitas mahasiswa. Sedangkan indikator yang paling dominan mempengaruhi kepuasan mahasiswa adalah profesionalisme dosen (Rahmawati, 2013). Manajemen pembelajaran daring tercapai dengan efektif apabila dosen menjalankan profesinya secara professional agar mahasiswa memperoleh kepuasan dan loyal pada kegiatan pembelajaran sehingga tujuan pembelajaran tercapai dengan efisien dan efektif.

\section{METODE}

Penelitian ini menggunakan pendekatan kuantitatif dengan jenis deskriptifkomparasi. Menggunakan analisis deskriptif bertujuan untuk mendeskripsikan atau menggambarkan fenomena yang ada baik yang bersifat alamiah maupun rekayasa manusia tentang manajemen pembelajaran, platform WA, CR, Z-M dan kesiapan mahasiswa untuk menerima perubahan strategi menjadi pembelajaran daring. Kesiapan perubahan dilihat dari respon mahasiswa dalam kemampuannya beradaptasi terhadap perubahan dan menerima perubahan. Alat ukurnya dari jumlah keluhan dalam penggunaan media online selama proses pembelajaran daring, partisipasi aktif dalam pembelajaran serta konsistensi mahasiswa dalam aktivitas pembelajaran. Analisis komparasi untuk mengetahui perbedaan proses perkuliahan dengan metode daring antara kelas $\mathrm{M}, \mathrm{K}$, dan kelas J.

Populasi penelitian ini adalah mahasiswa Jurusan Ekonomi Manajemen (EM) tahun ajaran 2019/2020 yang mengikuti mata kuliah "Pengantar Manajemen" pada kelas J, K dan M UPN "Veteran" Jawa Timur yang berjumlah 117 mahasiswa (seluruh populasi digunakan sebagai sampel/sampel sensus). Teknik pengumpulan data dengan platform Google Form. Selanjutnya data dianalisis dengan bantuan program analisis data statistik yaitu IBM SPSS Statistics 24.

\section{HASIL DAN PEMBAHASAN}

\section{Hasil Penelitian}

\section{Frekuensi Kelas Subyek Penelitian}

Mahasiswa yang mengikuti mata kuliah pengantar manajemen pada TA. 2019/2020 yang menjadi subyek penelitian ini berjumlah 107 mahasiswa, tetapi yang aktif dalam perkuliahan dan mengisi angket sejumlah 104 mahasiswa atau 95,41\%. Frekuensi kelas yang menjadi subyek penelitian:

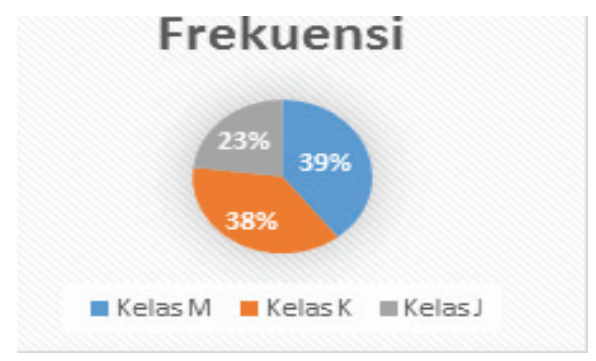

Gambar 1. Frekuensi Kelas Subyek Penelitian

Gambar 1 pada grafik menjelaskan bahwa kelas $\mathrm{M}$ berjumlah 41 orang $(39,4 \%)$, kelas $\mathrm{J}$ berjumlah 39 orang $(37,5 \%)$ mahasiswa, dan kelas $\mathrm{K}$ berjumlah 24 orang $(23,1 \%)$. Frekuensi kelas ini dapat mewakili karena 95,41\% mahasiswa dapat memberikan tanggapan terhadap penelitian ini. 


\section{Penggunaan Platform Group Whatsapp untuk Pembelajaran Daring}

Menurut persepsi mahasiswa, pemanfaatan Grup WA dalam pembelajaran daring sebagai berikut. Tabel 1. Platform Grup WA untuk Daring

\begin{tabular}{clccc}
\hline No. & \multicolumn{1}{c}{ Kategori } & Kode & Frekuensi & Persentase (\%) \\
\hline 1 & Sangat Tidak Setuju & 1 & 2 & 1,9 \\
2 & Tidak Setuju & 2 & 23 & 22,1 \\
3 & Ragu-Ragu & 3 & 0 & 0 \\
4 & Setuju & 4 & 66 & 63,5 \\
5 & Sangat Setuju & 5 & 13 & 12,5 \\
& $\quad$ Jumlah & & 104 & 100 \\
\hline
\end{tabular}

Platform grup WA kelas menurut persepsi 66 responden $(63,5 \%)$ setuju atau efektif digunakan dalam pembelajaran daring dan 13 orang (12,5\%) sangat setuju, karena platform ini murah atau tidak banyak memakan kuota dan sudah familiar. Dosen dapat memberikan materi PowerPoint disertai penjelasan dengan audio atau menjelaskan dengan voice note untuk menjelaskan pertanyaan mahasiswa. Sedangkan 23 mahasiswa $(22,1 \%)$ tidak setuju, dan 2 orang $(1,9 \%)$ sangat tidak setuju. Karakteristik siswa dan latar belakang mahasiswa mempengaruhi kepuasan dalam pelayanan pembelajaran menggunakan platform Whatsapps. Mahasiswa yang siap menerima WA lebih banyak dibanding yang tidak siap. Mereka tidak siap bukan karena tidak suka, tetapi lebih menyukai menggunakan Google Meet atau Zoom daripada WA dengan alasan karena mahasiswa dan dosen dapat bertatap muka melalui visual maupun audio.

\section{Pemanfaatan Platform Classroom untuk Pembelajaran Daring}

Hasil analisis dalam pemanfaatan Google Classroom untuk perkuliahan daring, dapat dilihat pada Tabel 2.

Tabel 2. Platform Classroom untuk Pembelajaran Daring

\begin{tabular}{clccc}
\hline No. & \multicolumn{1}{c}{ Kategori } & Kode & Frekuensi & Persentase (\%) \\
\hline 1 & Sangat Tidak Setuju & 1 & 0 & 0 \\
2 & Tidak Setuju & 2 & 8 & 7,7 \\
3 & Ragu-Ragu & 3 & 0 & 0 \\
4 & Setuju & 4 & 73 & 70,2 \\
5 & Sangat Setuju & 5 & 23 & 22,1 \\
& $\quad$ Jumlah & & 104 & 100 \\
\hline
\end{tabular}

Classroom sebagai platform dianggap efekfif oleh 73 mahasiswa $(70,2 \%)$ dan 23 orang $(22,1 \%)$ sangat setuju digunakan dalam pembelajaran daring karena efektif untuk menyampaikan materi berupa ppt dengan audio, video ataupun tanya jawab bahkan diskusi. Sebanyak 8 responden $(7,7 \%)$ tidak setuju platform classroom digunakan dalam pembelajaran daring. Apabila pertanyaan atau diskusi sudah panjang, maka respon di awal akan "sulit" dilacak, karena harus men"scroll" ke bawah lagi, dan schroll ke atas lagi. Hal ini menjadikan tidak efektif. Data ini bisa menjelaskan bahwa pemanfaatan platform classroom lebih dapat memuaskan kebutuhan mahasiswa meskipun terdapat kurang dari 10\% yang kurang mau "bekerja keras" sehingga muncul ketidaknyamanan. Kesimpulan sementara, platform Google Classroom dapat memuaskan kebutuhan mahasiswa dan efektif digunakan dalam pembelajaran daring (online).

\section{Pemanfaatan Platform Gmeet/Zoom Efektif untuk Pembelajaran Daring}

Hasil analisis persepsi mahasiswa dalam pembelajaran daring dengan memanfaatkan $\mathrm{M}-\mathrm{W}$ seperti Tabel 3 berikut. 
Tabel 3. Platform Zoom/G-Meet untuk Pembelajaran Daring

\begin{tabular}{clccc}
\hline No. & \multicolumn{1}{c}{ Kategori } & Kode & Frekuensi & Persentase (\%) \\
\hline 1 & Sangat Tidak Setuju & 1 & 0 & 0 \\
2 & Tidak Setuju & 2 & 26 & 25,0 \\
3 & Ragu-Ragu & 3 & 0 & 0 \\
4 & Setuju & 4 & 63 & 60,6 \\
5 & Sangat Setuju & 5 & 15 & 14,4 \\
& $\quad$ Jumlah & & 104 & 100 \\
\hline
\end{tabular}

Hasil analisis data dengan Platform Gmeet/Zoom disepakati oleh 63 mahasiswa (60,6\%) efektif dan 15 orang $(14,4 \%)$ sangat setuju digunakan dalam pembelajaran daring karena efektif untuk mengontrol kehadiran mahasiswa dan bisa berinteraksi tatap muka. Terdapat 26 mahasiswa (25\%) mahasiswa tidak setuju penggunaan gmeet/zoom karena biaya kuota lebih mahal dibanding platform yang lain. Jaringan internet juga menghalangi keefektifan platform ini karena tidak semua provider memiliki daya jangkau yang memadai untuk daerah tertentu. Sehingga mahasiswa tidak dapat mengikuti perkuliahan karena alasan tersebut.

\section{Hasil Analisis Frekuensi pada Perkuliahan Daring}

Pertimbangan dalam penggunaan pembelajaran online dari sisi mahasiswa adalah koneksi internet, terutama di daerah-daerah terpencil, terdepan dan tertinggal, dan mahasiswa yang terbebani jika menggunakan paket data yang cukup besar. Hasil selengkapnya digambarkan pada Tabel 4 berikut ini.

Tabel 4. Perkuliahan Daring

\begin{tabular}{|c|c|c|c|c|}
\hline No. & Kategori & Kode & Frekuensi & Persentase $(\%)$ \\
\hline 1 & Sangat Setuju & 1 & 32 & 30,8 \\
\hline 2 & Setuju & 2 & 49 & 47,1 \\
\hline 3 & Ragu-Ragu & 3 & 0 & 0 \\
\hline 4 & Tidak Setuju & 4 & 21 & 20,2 \\
\hline 5 & Sangat Tidak Setuju & 5 & 2 & 1,9 \\
\hline \multicolumn{3}{|c|}{ Jumlah } & 104 & 100 \\
\hline
\end{tabular}

Berdasarkan hasil analisis tentang pembelajaran daring (dari semua total platform) yang digunakan diperoleh keterangan bahwa 64 mahasiswa $(61,5 \%)$ tidak bisa memberikan penjelasan yang pasti. Mereka tidak merasakan perbedaan antara pembelajaran tatap muka ataupun pembelajaran daring. Mereka masih bisa menempuh atau mengikuti pembelajaran meskipun harus menyesuaikan diri terlebih dahulu terhadap platform yang digunakan dalam proses pembelajaran. Dan hanya 1 orang saja (1\%) yang sangat tidak setuju dan 18 orang (17,3\%) tidak setuju perkuliahan dilaksanakan dengan metode daring (tidak tatap muka). Alasan yang dikumpulkan dari responden antara lain karena alasan keterjangkauan jaringan, membutuhkan dana tambahan untuk membeli pulsa apalagi bila menggunakan google meet/ zoom. Banyaknya tugas setelah perkuliahan, karena semua dosen rata-rata memberikan tugas diakhir pertemuan dan waktunya relatif sempit. Mahasiswa yang setuju dan nyaman dengan perkuliahan daring sebanyak 20 orang $(19,2 \%)$, dan yang sangat setuju 1 orang (1\%). Secara umum, mahasiswa mempunyai keterampilan internet dan literasi komputer cukup baik, sehingga teknologi bukan menjadi masalah dalam pembelajaran daring.

\section{Pembelajaran Daring terhadap Pemahaman Materi}

Berdasarkan hasil analisis data, terkait dengan pemahaman materi dalam pembelajaran daring diperoleh gambaran seperti Tabel 5. 
Tabel 5. Pemahaman Materi pada Perkuliahan Daring

\begin{tabular}{clccc}
\hline No. & \multicolumn{1}{c}{ Kategori } & Kode & Frekuensi & Persentase (\%) \\
\hline 1 & Sangat Tidak Paham & 1 & 3 & 2,9 \\
2 & Tidak Paham & 2 & 30 & 28,8 \\
3 & Ragu-Ragu & 3 & 0 & 0 \\
4 & Paham & 4 & 52 & 50,0 \\
5 & Sangat Paham & 5 & 19 & 18,3 \\
& $\quad$ Jumlah & & 104 & 100 \\
\hline
\end{tabular}

Pada pembelajaran daring matakuliah Pengantar Manajemen, mahasiswa menyatakan sangat tidak paham sebanyak $2,9 \%$ dan tidak paham $28,8 \%$. Artinya $31,73 \%$ mahasiswa atau 33 mahasiswa yang menjadi subyek penelitian ini belum memperoleh kepuasaan, atau tidak memperoleh apa yang dibutuhkannya sehingga materi tidak dipahami dengan baik. Berdasarkan Rahmawati (2013), salah satu penyebab tidak tersampaikannya materi salah satunya adalah karena profesionalisme dosen dalam memanfaatkan media online dalam pembelajaran daring ini. Tetapi dalam hal pemahaman materi, 52 $(50,0 \%)$ atau setengah dari total mahasiswa menjawab paham dan $18,3 \%$ sangat paham pada materi yang disampaikan oleh dosen pengampu. Hasil analisa sementara ketidakpahaman mahasiswa dalam memahami materi adalah karena faktor lain-lain yang akan diteliti lebih lanjut.

\section{Perubahan Model Pembelajaran}

Perubahan model pembelajaran dari tatap muka menjadi daring, membuat mahasiswa dan dosen siap menerima perubahan strategi dalam pembelajarannya. Hasil selengkapnya dapat dilihat pada Tabel 6 berikut ini.

Tabel 6. Perubahan Model Pembelajaran

\begin{tabular}{|c|c|c|c|c|}
\hline No. & Kategori & Kode & Frekuensi & Persentase $(\%)$ \\
\hline 1 & Sangat Tidak Setuju & 1 & 0 & 0 \\
\hline 2 & Tidak Setuju & 2 & 19 & 18,3 \\
\hline 3 & Ragu-ragu & 3 & 0 & 0 \\
\hline 4 & Setuju & 4 & 71 & 68,3 \\
\hline 5 & Sangat setuju & 5 & 14 & 13,5 \\
\hline \multicolumn{3}{|c|}{ Jumlah } & 104 & 100 \\
\hline
\end{tabular}

Berdasarkan hasil analisis data menyebutkan bahwa perubahan pembelajaran menjadi daring tidak menjadi masalah/hambatan bagi 71 mahasiswa (68,3\%), dan bahkan 14,5\% sangat setuju. Jawaban dengan frekuensi 0 adalah jawaban dengan kategori sangat tidak setuju dan ragu-ragu. Meskipun 18,3\% tidak setuju karena tatap muka tetap menjadi pembelajaran yang dibutuhkannya.

\section{Hasil Analisis Persepsi Mahasiswa Terhadap Kendala Mengikuti Pembelajaran Daring}

Kendala yang dihadapi mahasiswa dalam pembelajaran daring ini dapat dilihat pada Tabel 7 berikut. Tabel 7. Kendala Pembelajaran Daring

\begin{tabular}{clccc}
\hline No. & \multicolumn{1}{c}{ Kategori } & Kode & Frekuensi & Persentase (\%) \\
\hline 1 & Terkendala kuota & 1 & 31 & 29,8 \\
2 & Terkendala jaringan & 2 & 42 & 40,4 \\
3 & Terkendala dosen & 3 & 7 & 6,7 \\
4 & Tidak ada kendala & 4 & 24 & 23,2 \\
5 & Ragu-ragu & 5 & 0 & 0 \\
& Jumlah & & 104 & 100 \\
\hline
\end{tabular}

Kuota menjadi kendala $29,8 \%$ responden, jaringan 40,4\%, dosen menjadi kendala $6,6 \%$ dan $23,2 \%$ tidak mengalami kendala. Secara umum dosen menjadi kendala mahasiswa dalam hal penyesuaian 
terhadap pengenalan platform yang akan digunakan dalam pembelajaran. Kuota menjadi kendala di awal peralihan, setelah diberikan bantuan dari perguruan tinggi kuota tidak terlalu menjadi masalah lagi. Jaringan menjadi kendala yang tidak bisa diatasi oleh mahasiswa dan dosen. Lingkungan termasuk dalam kendala jaringan.

\section{Hasil Analisis Uji Beda Terhadap Persepsi Mahasiswa pada Pembelajaran Daring Berdasarkan Kelas}

Penelitian ini menggunakan subyek penelitian dari kelas J, K dan M, dan dari ketiga kelas tersebut tidak berhubungan. Dengan menggunakan analisis One Way Anova dari IBM SPSS Statistics 24 diperoleh gambaran berikut tentang kelas dan pembelajaran daring.

Tabel 8. Hasil Uji Beda Terhadap Persepsi Mahasiswa pada Pembelajaran Daring

\begin{tabular}{lrrrrr}
\hline \multicolumn{1}{c}{ Total_X } & Sum of Squares & \multicolumn{1}{c}{ df } & Mean Square & F & \multicolumn{1}{c}{ Sig. } \\
\hline Between Groups & 7,150 & 2 & 3,575 & 0,182 & 0,834 \\
Within Groups & 1983,610 & 101 & 19,640 & & \\
Total & 1990.760 & 103 & & & \\
\hline
\end{tabular}

Berdasarkan hasil uji beda atau komparasi terhadap persepsi mahasiswa pada pembelajaran daring ini dengan menggunakan analisis satu arah (Anova) dari IBM SPSS Statistics 24 diperoleh penjelasan bahwa tidak ada perbedaan antara variabel kelas M, J ataupun K. Semua kelas yang terlibat dalam penelitian ini mempunyai kesamaan pendapat dalam perkuliahan daring. Hal ini dapat dilihat dari uji $\mathrm{F}$ sebesar 0,182 dengan signifikansi 0,834 dengan tingkat kesalahan 0,05 (5\%), oleh karena itu $\mathrm{H}_{0}$ diterima/ tak ditolak dan H1 ditolak/rejected. Dengan demikian dapat dijelaskan bahwa data dapat digunakan tanpa memisahkan kelas atau kelompok subyek penelitian.

\section{PEMBAHASAN}

Pembelajaran daring dengan memanfaatkan platform WA, CR atau M-Z mempunyai tujuan yang sama seperti juga pembelajaran tatap muka. Mahasiswa tidak perlu terlalu lama untuk beradaptasi dengan perubahan yang terjadi, karena pada dasarnya mahasiswa sudah banyak yang paham teknologi. Dosen menjalankan perannya sebagai fasilitator pembelajaran yang melayani mahasiswa dalam memenuhi kebutuhannya belajar dengan terus melakukan inovasi pembelajaran, mengembangkan kemampuannya dalam memanfaatkan teknologi dalam pembelajaran on line. Hasil penelitian ini berdasarkan kualifikasi sistem pembelajaran daring (Ehler \& Pawlowski, 2006) menunjukkan bahwa pemanfaatan platform Whatsapp, Classroom ataupun Zoom-Meet telah memenuhi klasifikasi kualitas, teknologi dan dapat menjadi sarana komunikasi yang menghubungkan (related) dosen dan mahasiswa dalam pembelajaran daring. Ketidakpuasan pada mahasiswa dalam pembelajaran daring karena ketidaksiapan mahasiswa untuk segera beradaptasi dengan perubahan.

Kepuasan mahasiswa dipengaruhi oleh profesionalisme dosen (Rahmawati, 2013) dan (Prasetyaningrum, 2009) menjelaskan bahwa kepuasan mahasiswa mempengaruhi loyalitas mahasiswa. Sedangkan indikator yang paling dominan mempengaruhi kepuasan mahasiswa adalah profesionalisme dosen (Rahmawati, 2013). Manajemen pembelajaran daring tercapai dengan efektif apabila dosen menjalankan profesinya secara professional agar mahasiswa memperoleh kepuasan dan loyal pada kegiatan pembelajaran sehingga tujuan pembelajaran tercapai dengan efisien dan efektif. Hasil penelitian menunjukkan bahwa adaptasi terhadap perubahan strategi pembelajaran dari tatap muka menjadi daring tidak menjadi masalah bagi mahasiswa, walaupun penyesuaian terhalang keterjangkaian jaringan, lingkungan dan faktor ekonomi tetapi mereka mendapat kepuasan. Dengan loyal dan terus mengikuti pembelajaran secara aktif karena dosen menggunakan platform yang bervariasi sehingga dapat memenuhi kebutuhan mahasiswa. Keterampilan internet dan literasi komputer mahasiswa dan dosen serta variasi pemanfaatan platform kunci untuk efektifitas dan efisiensi dalam pembelajaran daring. 


\section{SIMPULAN DAN SARAN}

\section{Simpulan}

Platform Whattapps dalam pembelajaran daring efektif digunakan dan dapat memenuhi kebutuhan mahasiswa dalam interaksi dengan dosen dan temannya. Dengan memanfaatkan fasilitas chating untuk memberikan informasi secara verbal, pengiriman file dari dosen yang dapat dipelajari mahasiswa, atau sarana komunikasi yang menghubungkan dosen dengan mahasiswa. Voice note dari dosen yang berisi penjelasan secara verbal dapat diterima oleh mahasiswa. Mahasiswa sebagian besar menyukai platform WA dan efisien karena tidak membutuhkan kuota yang banyak, dan tidak terhalang jaringan. Meskipun demikian agar tujuan pembelajaran bisa efektif diperlukan pemanfaatan platform yang lain sesuai dengan kebutuhan pembelajaran.

Pemanfaatan Classroom dianggap mahasiswa memenuhi kebutuhan karena interaksi pembelajaran dalam bentuk tanya jawab ataupun diskusi lebih terfasilitasi dibandingkan Whatsapp. Disamping terdapat kelemahan apabila diskusi sudah panjang maka chating menumpuk dan membuat mahasiswa malas untuk men"schroll" naik atau turun. Secara umum platform Classroom dapat memenuhi kebutuhan mahasiswa dalam pembelajaran daring.

Platform Gmeet/zoom secara umum dapat memenuhi kebutuhan mahasiswa karena efektif untuk mengontrol kehadiran mahasiswa dan bisa berinteraksi tatap muka. Apabila kemampuan dosen memadai dalam menggunakan fasilitas ini dan biaya kuota relatif tidak mahal, jaringan internet lancar dan memiliki daya jangkau yang memadai untuk semua daerah, maka platform ini bisa direncanakan untuk sering digunakan dalam pembelajaran daring.

\section{Saran}

Pembelajaran daring memerlukan perencanaan yang matang dan membutuhkan kesiapan dari dosen dalam merancang strategi pembelajarannya dengan mempertimbangkan kendala yang mungkin akan dihadapi dari sisi mahasiswa yaitu koneksi internet, terutama di daerah-daerah terpencil, terdepan dan tertinggal, dan beban kuota jika menggunakan paket internet. Pelaksanaan evaluasi pembelajaran seharusnya sesuai dengan norma assessment. Pemberian tugas setiap pertemuan akan menjadikan "beban", meskipun dengan tujuan agar mahasiswa lebih mendalami apa yang sudah dan akan dipelajari. Mahasiswa tidak merasa bahwa ada perbedaan antara pembelajaran secara online atau tatap muka. Meskipun pada awalnya harus beradaptasi dengan cepat dengan platform yang digunakan dalam proses pembelajaran, tetapi pada akhirnya mereka bisa menerima perubahan dan dapat melaksanakan kegiatan belajar seperti layaknya pembelajaran tatap muka.

\section{DAFTAR RUJUKAN}

Armenakis, A., Harris, S., \& Mossholder, K . 1993. "Creating Readiness for Organizational Change," Human Relation, vol. 46, no. 6, pp. 681-703, 1993.

Chandra, F. H., \& Nugroho, Y. W. 2017. Implementasi flipped classroom dengan video tutorial pada pembelajaran fotografi komersial. Desain Komunikasi Visual, Manajemen Desain dan Periklanan (Demandia), 20-36.

Duffy, F. M. 2010. The need for systemic transformational change in school districts (Part 1). 2009-02-03). http:// cnx. org/exports/1106db3a-3ed8-4944-b8ad-f85cc6b5637c@4.pdf/the-need-for-systemic-transformationalchange-in-school-districts-part-1-4. pdf.

Ehlers, U. D., \& Pawlowski, J. M. (Eds.). (2006). Handbook on quality and standardisation in e-learning. Springer Science \& Business Media.

Grant, A. M., \& Ashford, S. J. 2008. The dynamics of proactivity at work. Research in organizational behavior, $28,3-34$.

Hasibuan, M. S. 2008. Manajemen Sumber Daya Manusia: Jakarta, Indonesia: PT. Bumi Aksara.

Holt, Daniel., Armenakis, Field,S.,\& Haris, G. 2007. "Readiness for Organizational Change the Systematic Development of a Scale," The Journal of Applied Behavioral Science, vol. 43, no. 2, pp. 232-255, 2007.

Hussey, D.E. 2000. How to Manage Organizational Change. London: Kogan Page, Ltd. 
Ishak, T., Kurniawan, R., \& Zainuddin, Z. 2019. Implementasi Model Pembelajaran Flipped Classroom Guna Meningkatkan Interaksi Belajar Mahasiswa pada Mata Kuliah Manajemen Informasi dan E-Administrasi. Edcomtech Jurnal Kajian Teknologi Pendidikan, 4(2), 109-119.

Khusniyah, N. L., \& Hakim, L. 2019. Efektivitas Pembelajaran Berbasis Daring: Sebuah Bukti pada Pembelajaran Bahasa Inggris. Jurnal Tatsqif, 17(1), 19-33.

Kuntarto, E. 2017. Keefektifan Model Pembelajaran Daring dalam Perkuliahan Bahasa Indonesia di Perguruan Tinggi. Indonesian Language Education and Literature, 3(1), 99-110.

Lehman, W. E., Simpson, D. D., Knight, D. K., \& Flynn, P. M. 2011. "Integration of treatment innovation planning and implementation: Strategic process models and organizational challenges," Psychology of Addictive Behaviors, vol. 25, No. 2, p. 252.

Prasetyaningrum, I. D. 2009. Analisis Pengaruh Pembelajaran dan Kualitas Pelayanan terhadap Kepuasan Mahasiswa dan Loyalitas Mahasiswa (Studi Kasus pada Undaris Ungaran) (Doctoral dissertation, Program Pascasarjana Universitas Diponegoro).

Pratama, H., \& Yusro, A. C. 2016. Implementasi WhatsApp mobile learning untuk meningkatkan hasil belajar mahasiswa pokok bahasan Pengenalan Komponen Elektronika. Jurnal Pendidikan Fisika dan Keilmuan (JPFK), 2(2), 65-69.

Rahmawati, D. 2013. Analisis Faktor-faktor yang Mempengaruhi kepuasan mahasiswa. Jurnal Economia, 9(1), 52-65.

Salamah, Chuswatul Nur., Supriyanto., Gunawan, , Imam. 2020. Pengelolaan School Empowering Program dalam Mengembangkan Keahlian Khusus Siswa Sekolah Menengah Atas. Jurnal Adminitrasi dan Manajemen Pendidikan, Volume 3 Nomor 1 Maret 2020, http://journal2.um.ac.id/index.php/jamp/ ISSN 2615-8574 (online) h.: 1-10.

Stephens, J. C., \& Graham, A. C. 2010. Toward an empirical research agenda for sustainability in higher education: exploring the transition management framework. Journal of Cleaner Production, 18(7), 611-618.

Sukrillah, A., Ratnamulyani, I. A., \& Kusumadinata, A. A. 2018. Pemanfaatan Media Sosial Melalui Whatsapp Group Fei Sebagai Sarana Komunikasi. Jurnal Komunikatio, 3(2).

Syarifudin, A. S. 2020. Impelementasi Pembelajaran Daring Untuk Meningkatkan Mutu Pendidikan Sebagai Dampak Diterapkannya Social Distancing. Jurnal Pendidikan Bahasa dan Sastra Indonesia Metalingua, 5(1), 31-34. 